\title{
Neurological disease of Şehzade Cihangir in the Ottoman history: spinal dysraphism
}

\author{
Ali Ç. Turgut ${ }^{1}$ - Yașar B. Turgut ${ }^{2} \cdot$ Mehmet Turgut $^{3}$
}

Received: 11 November 2015 / Accepted: 13 November 2015 / Published online: 21 November 2015

(C) Springer-Verlag Berlin Heidelberg 2015

\section{Introduction}

Şehzade Cihangir (1531-1553 AD), the last born son of the Ottoman Sultan Suleiman the Magnificent and Sultan Hürrem, remains an intriguing figure in the Ottoman history (Figs. 1 and 2) (https://commons.wikimedia.org/wiki/ File:Khourrem.jpg, https://commons.wikimedia.org/wiki/ File:EmperorSuleiman.jpg). He was very well educated together with his elder brothers under supervision of his time, although he had some health problems since birth presenting as a big congenital hunchback. He wrote poems with the pen name "Zarifi" and he was also interested in calligraphy [1]. Cihangir and his brother Bayezid were circumcised with a grand ceremony on the Horse Square, when he turned 8 years old. Nevertheless, he refused to go to the sanjak because of his health problems and he lived in Istanbul all his life except for the two short

Mehmet Turgut

drmturgut@yahoo.com

Ali Ç. Turgut

alicaglar304.at@gmail.com

Yaşar B. Turgut

barroturgut@hotmail.com

Hacettepe University School of Medicine, 06100 Ankara, Turkey

2 Adnan Menderes University School of Medicine, 09100 Aydın, Turkey

3 Department of Neurosurgery, Adnan Menderes University School of Medicine, Cumhuriyet Mahallesi, Adnan Menderes Bulvarı, Haltur Apartmanı No: 6/7, 09020 Aydın, Turkey periods when he left the city: the second Iran expedition in 1548 and the third Iran expedition in 1553 [1].

In the third Iran expedition, Șehzade Cihangir together with his father Sultan Suleiman departed from Istanbul and reached the plains of Ereğli. Şehzade Mustafa, eldest son of Suleiman, also arrived with his troops from Konya [1]. Afterwards, as planned previously, Şehzade Mustafa was strangled by Sultan Suleiman's guards in 1553 [2]. Fortunately, Cihangir survived the event because he was in his father's tent. He was shocked by the situation since he was particularly fond of his half-brother Mustafa, and the army was demoralized when they heard about the event [1]. Historians reported that Cihangir's melancholy was understood as they arrived in Aleppo, and this frail young man could not tolerate this unbearable situation and the difficult journey. He also had some congenital health problems and finally passed away at the age of 23 in Aleppo (https://en. wikipedia.org/wiki/\%C5\%9Eehzade_Cihangir) [1]. The corpse of Cihangir was sent from Aleppo to Istanbul and was buried in the tomb of his deceased elder brother Şehzade Mehmed located in a special graveyard in front of the southern wall of the Şehzadebaşı Mosque [1].

Upon returning from the third Iran expedition (cover picture, Fig. 3) (https://commons.wikimedia.org/wiki/ File:Sueleymanname_nahcevan.jpg), Sultan Suleiman had Mimar Sinan build a mosque on the slope of today's Cihangir, one of the neighborhoods of the Beyoğlu district in Istanbul, Turkey, in memory of his deceased son Cihangir (https://en.wikipedia.org/wiki/\%C $\% \%$ 9Eehzade_Cihangir). During this period, the area was one of the favorite places of Suleiman's son Cihangir because it was of a wooded hunting ground (https://en.wikipedia.org/ wiki/Cihangir). In terms of language, the name of 


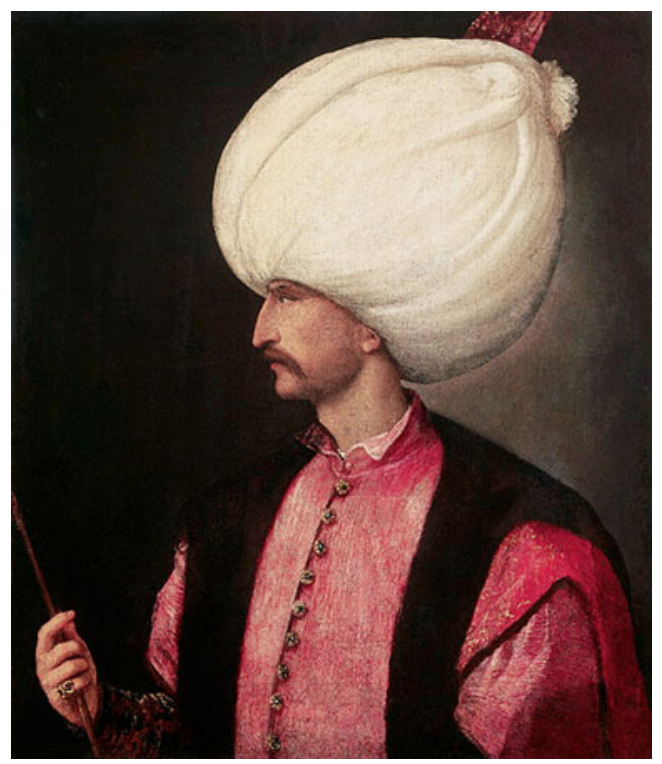

Fig. 1 Suleiman I (1495-1566 AD), a prominent monarch known in the West as Suleiman the Magnificent and in the East as the Lawgiver (Kanuni) in the sixteenth century Europe, presided over the apex of the Ottoman Empire (from https://commons.wikimedia.org/wiki/ File:EmperorSuleiman.jpg)

Cihangir, which comes from Persian, means "conqueror" in Turkish (https://en.wikipedia.org/wiki/Cihangir). The Cihangir Mosque was destroyed by the Istanbul earthquake of 1894 and then rebuilt by Abdülhamid Khan II [1]. Today, Cihangir, the most popular and ancient part of Istanbul, is named after the Şehzade Cihangir who was one of the most unique princes of the Ottoman Empire

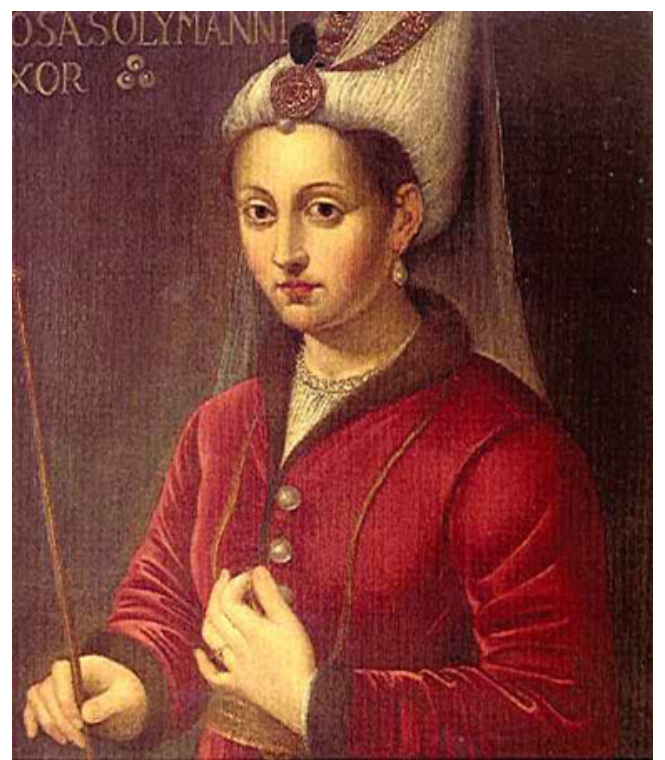

Fig. 2 Portrait of Alexandra Lisowska (1510-1558 AD), known in the West as Roxelana and in the Ottoman Empire as Sultan Hürrem, the wife of Suleiman the Magnificent (from https://commons.wikimedia.org/wiki/ File:Khourrem.jpg)

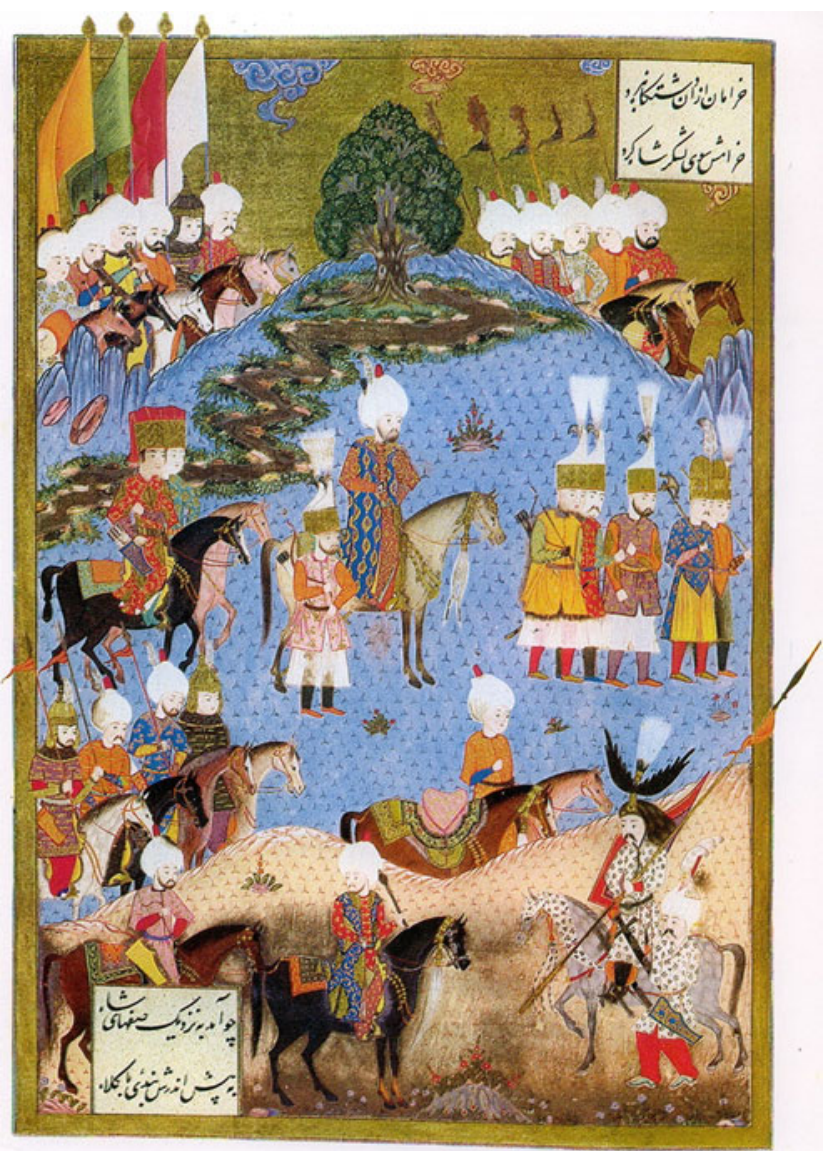

Fig. 3. The cover picture shows Suleiman the Magnificent marching with the army in a miniature from the Süleymanname of Matrakçı Nasuh and other painters at the Topkap1 Palace, Istanbul, in the sixteenth century. Please also note that the presence of poems in Persian language written at the two corners of the miniature (from https:// commons.wikimedia.org/wiki/File:Sueleymanname_nahcevan.jpg)

(Fig. 4) (https://commons.wikimedia.org/wiki/File:\%C5\% 9Eehzade_Cihangir_Camii_3.jpg).

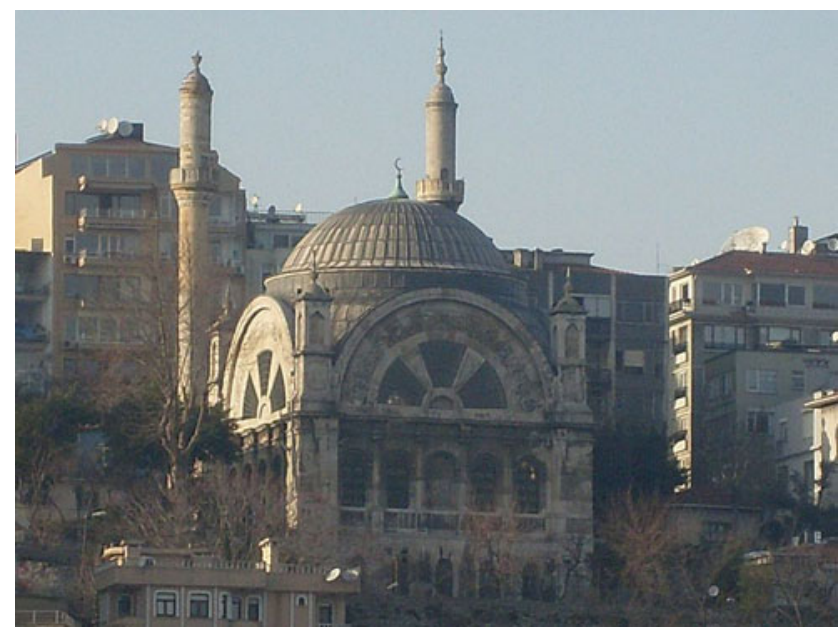

Fig. 4 Picture of the current Șehzade Cihangir Mosque in Istanbul, Turkey (from https://commons.wikimedia.org/wiki/File:\%C5\% 9Eehzade_Cihangir_Camii_3.jpg) 


\section{Scientific evidence for spinal dysraphism}

Historically, it is well known that a neurological disease may alter the course of human history as the majority of the cases present with chilling effects or tragic outcome. It has been reported that Șehzade Cihangir had a big congenital hump on his back called "hunchback," and there was a remarkable spinal curvature in the upper part of his body [1]. Morphologically, one shoulder was higher than the other and there was a curvature in the ribs [1]. More importantly, as understood from the letters of his mother Sultan Hürrem, there were large unhealed wounds on the skin covering the hunchback [1]. Moreover, as the youngest child in the family and as a result of his disability, Cihangir was loved and treated exclusively a lot like all of the last descendants, but unfortunately he could not recover [1].

Based on our current knowledge, the reported findings clearly indicate that Şehzade Cihangir was most probably suffering from "spinal dysraphism" associated with kyphoscoliosis presented with a rounded gibbous in the cervicothoracic region due to anomalous development in the embryo. Pathological point of view, it is possible that there was an abnormal fusion of the midline embryonic neural, vertebral, and mesenchymal structures. Basically, it can be broadly divided to into two different pathological entities: open spinal dysraphism (meningocoele, myelomeningocele) and closed spinal dysraphism (dorsal dermal sinus, lipomyelomeningocele, diastematomyelia, neurenteric cyst, thickened filum terminale) [3]. In fact, history of Șehzade Cihangir helps us understand the complexity of the neurological disease because it has a full impact on humanity.

\section{Outcome of Șehzade Cihangir's neurological disease}

In clinical practice, some types of spinal dysraphism do not provide neurological findings, while others might result in complete loss of muscular strength and sensation and even sphincter dysfunction [3]. Today, it also is known that a deteriorated life quality and psychological problems due to associated congenital anomalies of cardiovascular and urinary systems are widespread especially among children and young adults with serious types of spinal dysraphism. Thus, one may suggest that Cihangir was born with a kind of spinal dysraphism, but this tragedic story is a cautionary example of the negative effects of spinal dysraphism and its neurological complications upon the life quality of children. Over the years, the understanding of pathophysiology has made a significant change in the management of these anomalies. Nevertheless, patients with spinal dysraphism might complain from backache and restrictive pulmonary disease due to severe congenital spinal deformity and a deformed chest, resulting in an increased risk of pneumonia and death. Șehzade Cihangir went on military expeditions on the horse along with his father, and it is strongly expected that such a journey would deteriorate complaints of the patient [1]. On the other hand, it is also rumored that Cihangir died because of the deep sorrow after the news of the murder of his half-brother, Şehzade Mustafa (https://en.wikipedia.org/wiki/\%C5\%9Eehzade_ Cihangir) [1]. It is strongly possible that, like Cihangir, a person who loses a close relative becomes deeply depressed, known as a psychological major depression.

\section{Compliance with ethical standards}

Conflict of interest The authors declare that they have no competing interests.

\section{References}

1. Uğurluel T, Kayatekin M (2015) History made the medicine speak: assassinations, mystery deaths, mysterious events (in Turkish). Timaș Publications, Istanbul

2. Turgut AC, Turgut YB, Turgut M (2015) Murder of Şehzade Mustafa as an ordinary but very painful event in terms of the Ottoman history. Childs Nerv Syst. doi:10.1007/s00381-015-2882-4

3. Martínez-Lage JF, Pérez-Espejo MA, Hoving E (2010) Cranial and spinal dysraphisms. In: Lumenta CB, Di Rocco C, Haase J, Mooij JJA (eds) Neurosurgery. Springer, Berlin Heidelberg, pp. 485-499 